\title{
KEWAJIBAN WARGA NEGARA HARUS MINUM VITAMIN DAYA TAHAN TUBUH DISAAT PANDEMI
}

ARTHA DWI SHAFIRA PAWESTRI

S1 FARMASI

IIK STRADA Indonesia

Safiraarta664@gmail.com

\begin{abstract}
ABSTRAK
Vitamin adalah senyawa organik yang banyak terdapat dalam sayur dan buah yang kita konsumsi. Vitamin dan mineral diperlukan oleh tubuh untuk menunjang kinerja organ tubuh kita sehari-hari. Tanpa asupan vitamin dan mineral yang cukup, kita dapat mengalami gejala fisik. Contohnya, saat tubuh kekurangan vitamin $\mathrm{C}$ kita dapat mengalami sariawan atau gusi berdarah; kita bisa mengalami beri-beri saat kekurangan vitamin B1; dan kekurangan vitamin $D$ dapat menyebabkan penurunan imunitas. Dan suplemen adalah zat tambahan yang mengandung nutrisi baik untuk tubuh kita. Suplemen diolah di pabrik dan diproduksi dengan berbagai rupa: pil, kapsul, tablet, ataupun cairan. Satu jenis suplemen pada umumnya mengandung beberapa vitamin dan mineral yang diperlukan tubuh. Kita dapat mengonsumsi suplemen tambahan dengan dosis minimal jika kita tidak mendapatkan berbagai zat tersebut secara alami dari makanan kita sehari-hari. Tentu saja, kebutuhan seseorang terhadap vitamin dan mineral spesifik pada kondisi tubuh setiap orang. Vitamin dan mineral tetap diperlukan untuk menunjang kinerja tubuh kita meskipun kita sedang beraktivitas di rumah saja. Utamanya, sebagian besar kebutuhan ini dapat terpenuhi ketika kita memiliki pola makan yang baik. Kebutuhan gizi setiap orang akan berbeda-beda. Zat gizi seperti karbohidrat, protein, lemak, vitamin, mineral, serat dan air tetap harus disesuaikan kembali dengan kebutuhan seseorang berdasarkan usia, jenis kelamin, berat badan dan tinggi badan, aktivitas fisik dan kondisi spesifik yang sedang dialami seseorang.
\end{abstract}

\section{- LATAR BELAKANG}

Suplemen adalah zat tambahan yang mengandung nutrisi baik untuk tubuh kita. Suplemen diolah di pabrik dan diproduksi dengan berbagai rupa: pil, kapsul, tablet, ataupun cairan. Satu jenis suplemen pada umumnya mengandung beberapa vitamin dan mineral yang 
diperlukan tubuh. Kita dapat mengonsumsi suplemen tambahan dengan dosis minimal jika kita tidak mendapatkan berbagai zat tersebut secara alami dari makanan kita sehari-hari. Tentu saja, kebutuhan seseorang terhadap vitamin dan mineral spesifik pada kondisi tubuh setiap orang. Untuk mencegah agar tidak terpapar COVID-19, pertama-tama kita harus tetap menjalankan protokol kesehatan: mencuci tangan dengan sabun, memakai masker, dan menjaga jarak. Peranan vitamin dan mineral adalah untuk mencegah agar imunitas kita tidak menurun, sehingga dapat menangkal terjadinya komplikasi akibat COVID-19.Vitamin dan mineral tetap diperlukan untuk menunjang kinerja tubuh kita meskipun kita sedang beraktivitas di rumah saja. Utamanya, sebagian besar kebutuhan ini dapat terpenuhi ketika kita memiliki pola makan yang baik. Kebutuhan gizi setiap orang akan berbeda-beda. Zat gizi seperti karbohidrat, protein, lemak, vitamin, mineral, serat dan air tetap harus disesuaikan kembali dengan kebutuhan seseorang berdasarkan usia, jenis kelamin, berat badan dan tinggi badan, aktivitas fisik dan kondisi spesifik yang sedang dialami seseorang. Selain mencukupi nutrisi tubuh, kita juga harus terus melakukan aktivitas fisik agar vitamin dan segala nutrisi yang telah masuk ke dalam tubuh bisa dengan efektif menunjang kinerja tubuh kita. Aktivitas fisik bisa berupa: olahraga, memasak, bersih-bersih rumah, dan masih banyak lagi. Selain untuk menyehatkan tubuh, aktivitas fisik juga mampu mengeluarkan hormon stres sehingga tingkat imunitas bertambah. Upaya meningkatkan imunitas memang tidak bisa dengan cara sekadar memperbaiki satu faktor saja, melainkan mencari keseimbangan di antaranya: makanan, minuman, aktivitas fisik, durasi serta kualitas tidur, hingga tingkat stres.

\section{- TINJAUAN PUSTAKA}

Suplemen diartikan sebagai zat aditif yang mengandung nutrisi baik bagi tubuh. Jika vitamin bersifat organik dan berasal dari makanan atau buah-buahan, suplemen umumnya di produksi secara mekanik. Suplemen yang diolah secara mekanik ini (olahan pabrik) biasanya berbentuk pil, tablet, kapsul, ataupun berbentuk cairan. Karena di produksi, suplemen umumnya mengandung lebih dari tiga macam vitamin dan mineral yang dibutuhkan oleh tubuh .Suplemen akan menjadi substansi yang berbahaya jika dikonsumsi melebihi takaran atau dosis yang sudah ditentukan. Hal tersebut tentu saja disebabkan oleh banyaknya mineral dan vitamin yang terkandung di dalam suplemen. Beberapa kalangan membutuhkan vitamin, seperti vegetarian yang mengalami kekurangan vitamin B12 atau B5. Selain itu, sebagian orang yang tidak menyukai sayuran atau buah atau memiliki alergi juga dianjurkan untuk mengonsumsi suplemen. 


\section{- PEMBAHASAN}

1) Pengertian vitamin

Vitamin adalah sekelompok senyawa organik berbobot molekul kecil yang memiliki fungsi vital dalam metabolisme setiap organisme yang tidak dapat dihasilkan oleh tubuh. Terdapat 13 jenis vitamin yang dibutuhkan oleh tubuh untuk dapat bertumbuh dan berkembang dengan baik. Vitamin tersebut antara lain vitamin $A, C$, D, E, K, dan B (tiamin, riboflavin, niasin, asam pantotenat, biotin, vitamin B6, vitamin B12, dan folat). Walau memiliki peranan yang sangat penting, tubuh hanya dapat memproduksi vitamin $\mathrm{D}$ dan vitamin $\mathrm{K}$ dalam bentuk provitamin yang tidak aktif. Sumber berbagai vitamin ini dapat berasal dari makanan, seperti buah-buahan, sayuran, dan suplemen makanan.

2) Pengertian suplemen Suplemen adalah produk-produk yang mengandung satu atau lebih nutrien vitamin, mineral, asam amino, asam lemak, dan serat. Selain itu, suplemen juga dapat berupa produk-produk alami berupa herba ataupun bahan alami non tumbuhan, misalnya yang didapatkan dari hewan.

a. sumber-sumber zat gizi yang dibutuhkan dalam rangka menjaga kesehatan tubuh kita:

1. Protein

Sebagai tulang punggung dari mekanisme pertahanan tubuh karena antibodi dan sel yang berfungsi menjaga kekebalan tubuh lainnya terbuat dari protein. Bahan makanan sumber protein terdapat pada: telur, susu, yoghurt, keju, makanan berbahan kedelai, ikan dan daging. Selain itu, protein berkualitas tinggi juga dapat ditemukan dalam kombinasi sayuran, biji-bijian, dan kacang-kacangan.

\section{Vitamin A}

Sebagai penguat dan pengatur salah satu organ kekebalan tubuh yang paling penting yaitu : kulit, saluran pencernaan, dan paru-paru. Bahan makanan sumber vitamin A terdapat pada: buah dan sayur tang berwarna oranye terang, merah, dan hijau, seperti pada : ubi. wortel, paprika merah, telur, dan sayuran hijau lainnya.

\section{Vitamin C}

Memiliki kemampuan yang utama dalam menjaga kekebalan tubuh, dimana bisa merangsang pembentukan antibodi yang mengikat racun berbahaya sebelum menghancurkannya. Bahan makanan sumber vitamin $\mathrm{C}$ terdapat pada: aneka macam jeruk, strawberry, pepaya, paprika merah, dan tomat.

\section{Vitamin $\mathrm{E}$}

Memiliki kemampuan dalam menunjang peran vitamin $C$ untuk menjaga kesehatan dan mengusir penyebab-penyebab dari luar yang dapat menyebabkan tubuh terkena penyakit Bahan makanan sumber vitamin E terdapat pada biji-bijian utuh, atau sereal yang diperkaya oleh biji-bijian seperti: bunga matahari, kacang-kacangan, dan minyak sayur. 


\section{- KESIMPULAN}

Hampir semua warga negara Indonesia sulit untuk mengonsumsi vitamin sehingga banyak yang terserang penyakit terutama terserang virus corona. Kita harus menjaga kesehatan tubuh kita di saat pandemi maupun tidak, agar tetap sehat dan tidak mudah terserang penyakit. Dan kita harus rajin berolahraga agar fisik kita tetap terjaga.

\section{- DAFTAR PUSTAKA}

fak.kesehatan, a. (2021, juni). Diambil kembali dari pentingnya minum suplemen daya tahan tubuh selama pandemi: https://fikes.unisayogya.ac.id/pentingnya-minum-suplemen-daya-tahantubuh-selama-pandemi/

dr.kristina joy herlambang.BMedScl(Hons), M. (2021, Januari). Diambil kembali dari Seberapa Penting Minum Vitamin atau Suplemen Selama Pandemi COVID-19: https://www.emc.id/id/care-plus/seberapa-pentingnya-minum-vitamin-atau-suplemenselama-pandemi-covid19

admin. (2020, july). Diambil kembali dari POLA HIDUP SEHAT SELAMA MENGHADAPI PANDEMI COVID 19: https://blitarkota.go.id/id/berita-opd/pola-hidup-sehat-selama-menghadapi-pandemicovid19

Setyani, A. T., \& Sodik, M. A. (2018). Pengaruh Merokok Bagi Remaja Terhadap Perilaku dan Pergaulan Sehari-hari. 